\title{
MAY 8th
}

As in previous years, World Red Cross Day in 1965 was celebrated on May 8th. On the occasion of this 137th anniversary of Henry Dunant's birth - which was also the 20th anniversary of the cessation of the Second World War - the press and radio recalled the work of the Red Cross and the memory of the movement's founder, whilst the National Red Cross, Red Crescent and Red Lion and Sun Societies, for their part, decided to mark the event by various celebrations, some of which we mention below.

In Switzerland, teachers were invited by the Swiss Junior Red Cross to devote time in their lessons on May 8 th to the subject of the Red Cross. The Swiss Juniors undertook a campaign to collect books with which to form school libraries in the mountain villages.

In Canada, the National Society organized a speech contest open to high school students, the subject being this year's Red Cross Day theme. The two prize winners - one English and one French speaking - will be given a two week holiday in Geneva including visits to the International Red Cross institutions in that town.

In the Congo, youth education, the subject for the first year (1965) of the Juniors' Five Year Plan, was the theme for a speech and drawing competition on the occasion of World Red Cross Day.

The Dahomey Red Cross launched a large-scale publicity campaign, with the accent on the organization of a Junior Red Cross branch. On May 8th a procession of children paraded through the streets of Cotonou, the capital.

In Indonesia, teachers agreed to explain on that day the humanitarian principles and their importance in the world today.

In Ireland the Juniors undertook a drive for funds to increase their country's contribution to the F.A.O.'s " Freedom from Hunger Campaign " in the form of a model village and experimental farm which Ireland has started in Tanzania for 250 families.

In the Republic of Korea the Junior Red Cross decided to be foster parent for orphans, as its action for World Red Cross Day.

In Nigeria the Juniors chose health education as the field in which they would commemorate Henry Dunant's birth, by posting up notices on the principles of hygiene, by cleaning schools, streets, reception centres, etc.

In Tanzania, the day was devoted to a recruiting campaign. 
The whole country was bedecked with Red Cross flags and the commemorative programme included processions, first-aid demonstrations, and the award of certificates to blood donors and the most active members of the Junior Red Cross.

Red Cross Day, which this year was devoted to youth, had as its theme - as already mentioned in a recent issue of the International Review - “Red Cross Youth : To-morrow's Strength To-day”. It is worth mentioning that on this occasion Dr. M. G. Candau, Director General of the World Health Organization, in a message which we reproduce below, paid tribute to the humanitarian work being accomplished day after day under the three emblems of our movement :

On the occasion of World Red Cross Day, I have great pleasure in addressing the 68 million young people who serve the ideal of the Junior Red Cross and in a great movement of solidarity further its noble aims: "Protection of Health and Life, Service and International Friendship ".

These millions of young people are the advance guard of a peaceful army. They should be fully aware of the responsibilities falling upon them.

The World Health Organization attaches great importance to health education, the first theme of action of the new Junior Red Cross Programme. It sees in it an essential means of ensuring wider understanding of public health measures.

To prepare for a healthy future is the great task awaiting the rising generation. It therefore has to fight against illness. Malaria, a disease representing the heaviest financial burden for the world, must be eradicated just like yaws with its terrible mutilations. Smallpox should be eliminated from the list of great scourges and also tuberculosis, poliomyelitis, cancer and cardiovascular diseases. The Junior Red Cross can here play a vital preventive rôle, thus contributing essential support in the difficult fight for health, which in the words of the Constitution of our Organization is a "state of complete physical, mental and social wellbeing. ..."

In addition and for the sixteenth year in succession, an important international radio broadcast by the Red Cross took place on 
the evening of May 8 th. In the course of this programme, broadcast under the auspices of the International Committee, the League, the European Broadcasting Union, and the International Radio and Television Organization, listeners were able to hear, by " multiplex" a series of calls from 22 stations in Europe, America and Africa.

The programme was then split up among several wave-lengths. The French broadcast was a "flash-back" arranged for broadcasting through Radio-Genève by Mr. Georges Hardy and was transmitted by the Swiss, French, Belgian, Canadian, Radio-Luxembourg and Radio-Monte-Carlo networks. A joint German language broadcast was transmitted by the Federal Republic of Germany, Austria and the German-speaking part of Switzerland ; the Democratic Republic of Germany had its own programme. An Italian language broadcast was transmitted from the radio networks of the Tessin, Italy and the Vatican. A special broadcast was prepared by the Swiss Short Wave Service for English and Spanish listeners.

Other countries broadcast their own national programmes based on material supplied by Geneva.

Thus, again this year, numerous countries illustrated the unity and universality of the Red Cross by their programmes on the air, either direct or relayed.

In conclusion we would mention that a brief ceremony took place on the morning of May 8th before the Henry Dunant monument in the Parc des Bastions, Geneva, Many Red Cross officials attended, representing the ICRC, the League and the Swiss Red Cross.

Wreaths were laid on the monument; as a reminder that World Red Cross Day was this year devoted to youth, the first was laid by two Junior groups of the Geneva branch of the Swiss Red Cross Society. The second wreath was a joint offering by the League, the ICRC and the Swiss National Society; the third was laid by the Chargé d'Affaires of the Norwegian Permanent Mission to Geneva on behalf of the Norwegian Red Cross which is this year celebrating the centenary of its foundation.

Once again the World Red Cross, Red Crescent and Red Lion and Sun Day aroused wide interest and was celebrated in 'a worthy manner enabling many countries to pay tribute to the memory of Henry Dunant. 